\title{
Mother Experience Treating Child With Leukemia in The Hemato-Oncology Ulin Hospital Banjarmasin
}

Nita Kusuma Lindarsih ${ }^{1}$,

${ }^{1}$ Sari Mulia Midwifery Academy Banjarmasin

*nitakusuma.170114@gmail.com

YP. Rahayu ${ }^{1}$

${ }^{1}$ Sari Mulia Midwifery Academy Banjarmasin

yayu_piji_rahayu@akbidsarimulia.ac.id

Dwi Sogi Sri Redjeki ${ }^{1}$

${ }^{2}$ Sari Mulia High School of Health Sciences

Dwi_sogi_sri_redjeki@stikessarimulia.ac.id

\begin{abstract}
Objective: To identify the experience of the mother caring for the child with Leukemia.

Method: This type of research used qualitative research method with descriptive phenomenology design. Data collection with in-depth interview technique with key informant were 4 mothers who had children with leukemia and 3 informants triangulation ie 2 husbands and 1 nurse in the hematooncology room of RSUD Ulin Banjarmasin. The technique of processing and data analysis result of interview through 3 stages namely, data reduction, data presentation, and making a conclusion.

Results: The first mom's experience of knowing a child being diagnosed with leukemia is shock, shock, and sadness because the child suddenly experiences chronic illness and the mother reacts to cry when she first hears a child being diagnosed with leukemia. The problems faced by mothers during the care of children in the hospital that is the cost of care is expensive but the mother use the help from the government that is BPJS and mothers get a lot of assistance such as social and material support.
\end{abstract}

Conclusion: During the care of a child with maternal leukemia more grief than the likes of having to care for his sick child and undergoing a long treatment at the hospital.

Keywords: caring for children, leukemia, hemato-oncology, mother's experience.

\section{INTRODUCTION}

Genetic abnormalities are one of the factors causing leukemia disease. Leukemia is a malignant disease occurring in white blood cells, characterized by excessive early proliferation [1].

Leukemia is the most common type of cancer in children with an incidence of $31.5 \%$ of all cancers in children under 15 in industrialized countries and as many as $15.7 \%$ in developing countries. Yayasan Onkologi Anak Indonesia states as many as $30 \%-40 \%$ of the incidence of cancer in children is leukemia or blood cancer of about 3.850 children. Leukemia mortality rate in Indonesia reaches $50-60 \%$ due to the limited knowledge of the community about the dangers of cancer.

Chronic diseases such as leukemia in children cause a negative impact on the child 
and on the mother who is the primary caregiver. They will find it difficult to understand the feelings and conditions experienced. Ignorance of the needs and financial care of the family and social life also affect the psychological and physical parent, especially the mother [2]. The psychological impact on mothers who have children suffering from leukemia will be faced with challenges in accepting and adapting to their children such as stress, lifestyle changes, and financial distress. In addition to adapting to the condition of the child, the mother also struggles to be able to face the pressure in medication and confusion in facing the future for her child [3].

The phenomenon of leukemia in children that happened in Ulin Banjarmasin hospital that is leukemia become the cause of death number 1 in child with data obtained leukemia patient in child treated in RSUD Ulin Banjarmasin Hemato-oncology room of child from January-December year 2016 counted 586 children with lymphoblastic leukemia acute (ALL) because the mother is less informed about leukemia and leukemia causes cannot be known early so that the mother late to bring her child to the health worker and his child's illness is severe.

The preliminary results of the discussion with interviews on 3 mothers who had children with leukemia were performed in the Hemato-Oncology Room of Ulin Banjarmasin Children's Hospital found that 1 out of 3 mothers have low knowledge, this is proven when the mother difficulties mention the name of the illness suffered by the child even mother does not know the cause of the disease. 1 out of 3 other mothers said her child's illness was already severe because it was too late to bring to the hospital because the mother considered her child's disease just ordinary. Another mother said her child was always embarrassed when she met other people and even her friends and did not get social support from the family. All mothers said they were worried about their child's condition and had financial difficulties in taking care of their sick child. All mothers expect their children to recover quickly and can have a good education for their future, so researchers interested in conducting research on the mother's experience of caring for children with leukemia in the HematoOncology room Ulin Hospital Banjarmasin.

\section{METHOD}

This type of research uses qualitative research methods with descriptive phenomenology design. In this research the method of data collection using the method of the in-depth interview (In-depth Interview) to the main informant by digging deeper and more information. Informant of this research consists of 4 mothers who have children with leukemia as the main informant, and 2 husbands from a mother who has children with leukemia and 1 nurse space hematooncology as informant triangulation. 


\section{RESULTS}

\section{Mother's Experience About How To} Take Care Of Children With Leukemia

a. Feelings that mom felt when the first time the child was diagnosed with leukemia.

All mothers who have children with leukemia will surely feel shocked, shocked, sad, not accept the fact, confused and there is a feeling of rejection when the first time a child is diagnosed with leukemia due to undergo long treatment.

b. The reaction of the mother at the first time the child is diagnosed with leukemia

Mother's reactions vary when she learns that her child is suffering from a chronic illness like that of a mother who has a child with leukemia. The first reaction some moms hear that her child is diagnosed with leukemia is crying.

c. Treatments that a child must have with leukemia

Parent's business includes all the efforts that parents have done during their child's care. Both when symptoms of leukemia appear and during therapy. In this study found some efforts made by parents in dealing with leukemia include alternative medicine, dieting (eating/drinking), arranging children's activities, and routine leukemia treatment.
1) Alternative Medication

All mothers would want a cure for their children, some informants provide an alternative treatment for their children with leukemia such as bringing to a smart person or with traditional ingredients.

2) Dieting (eating/drinking)

Some mothers declare to avoid eating and drinking their children like preservatives and artificial sweeteners.

3) Organizing Children Activities

Some mothers regulate the daily activities of children to keep activities and rest balanced for the health of children. mothers give direction to the child to rest because if too much activity will affect health in children and will worsen the state of the sick child.

i. Regular treatment of leukemia

Some mothers know that treatment should be treated by children with leukemia.

Love the grief that mother experienced during caring for a child with leukemia

Grief must be experienced by every mother who has children who suffer from leukemia because they have to undergo a long treatment.

\section{Problems facing the mother when} caring for children with leukemia

a. Problems that mothers face during childcare. All mothers have similar problems during the treatment of children with leukemia. Treatment and treatment in children with leukemia requires a very large cost. Economic difficulties are a 
major problem facing mothers during child care and treatment.

b. The way the mother overcomes the problems faced

various kinds of efforts that mothers do to overcome the problems faced by mothers during caring for children with leukemia. In terms of the cost of all mothers using the government's help, the BPJS (Social Security Administering Body) that helps parents ease the cost of care and treatment in children with leukemia.

c. Help that mothers receive during caring children with leukemia

Some mothers who treat children with leukemia receive help from the surrounding environment, family and close friends even from foundations that care about cancer in children such as social support and material assistance such as:

\section{ii. Social Support}

Some mothers receive social support from family, close friends, from mothers who have children with leukemia and from health workers. Social support provided such as motivation, passion, and information on child care.

iii. Material Support

Material assistance is needed by all mothers who care for children with leukemia because it requires a lot of cost for care and treatment. Mothers receive material assistance such as money, food, and gifts, as the informants disclosed as follows:

b. Impacts that occur in children The effects that occur in children with leukemia include the impact that occurs on the physical and the impact on the education as follows:

1) Impacts that occur on the physical Children who undergo chemotherapy will experience side effects from chemotherapy such as cough colds, fever.

2) Impacts on Education

Most mothers experience obstacles to the education of children, there are those who should be absent from school and who to quit school due to the physical condition of children who are not possible and must undergo a long treatment.

c. Mother's expectation for the condition of the child in the future

All mothers have the same hope for the condition of their child who suffers from leukemia is the healing of his son.

\section{DISCUSSION}

1. The Mothers' Experience in How to Take Care of Children With Leukemia

a. Feelings that mom felt when the first time the child was diagnosed with leukemia

From the results of this study found that mothers who care for children with leukemia experience profound sadness, 
shock, shock, disbelief and do not accept the fact that children have leukemia disease that should undergo a long treatment. This is also supported by Cohen's theory which states that emotional responses in the form of feelings of sadness, confusion, and anxiety are the first things felt by the family when they know their child is suffering from chronic illness and will depend on his life for treatment and care.

Mothers in this study said they felt sad and disbelieving when they learned that their child had leukemia disease where their hope of seeing children grow and develop like other healthy children did not match the fact that they had to be in hospital and undergo a long treatment as written by Koblenzer [4] from the results of his research states about the mother's emotional response when knowing her child suffering from chronic diseases. Where the expectations of the individual towards their children greatly affect their feelings.

a. The reaction of the mother at the first time the child is diagnosed with leukemia

All the informants expressed the mother's reaction when she heard her child was diagnosed with maternal leukemia immediately crying. This is supported by the results of research Cornelio et al states that the mother was surprised when they heard the diagnosis of children and had to go through the process of sadness, and gradual acceptance has occurred. Many mothers feel emotionally unstable and cry when they hear the diagnosis

Based on this research, the informant reveals that the mother experiences a series of processes in acceptance of her child's circumstances and must go through the process of sadness including in denial stage or rejection, mother's first reaction when knowing her child is diagnosed leukemia all mother crying because child condition not according to expectation, because they think leukemia will lead to death. All mothers would not want to see her child sick and lying weak. This is supported by the theory of Kubler-Ross one will experience the first stage of mourning denial/rejection that is when the mother tries to forget or hide reality, the individual behaves as if nothing happened and refuses to believe that he or she has lost, the second is the individual anger being opposed or against the loss that occurs, feels God unjust or unfeeling of the reality that must be faced, the third stage bargaining is the individual to bargain to do good if extended his life as the thing he experienced can be prevented, the fourth stage of depression / depression that the individual realizes 
that the impact and meaning of loss when he feels himself and withdraws from the interaction, the last stage of acceptance that individuals can accept the loss start receiving the future.

b. Treatments that a child must have with leukemia

The results of this study children continue to take medication to the hospital to undergo chemotherapy and the mother still seek traditional medicine for the healing of his son such as bringing to the smart and demihuman herbal concoctions. It is also written by Putri [5] from the results of his research stated that parents seek various things to speed up the recovery of their children one of them is to combine medical treatment with traditional medicine. Some of his participants revealed using herbal concoctions that have been formulated in the form of bottles, as a companion medical treatment and went to smart people to ask for Shari'a. After many efforts made by the parents there is no change in the condition of the child, start the parents bring to the health service from coming to the clinic, public health center, to the hospital.

Informants in this study stated that they should limit their children activities such as reducing play, socializing with others, not walking too far and more rest to avoid recurrence in children and physical child awake. It is also written by Hernanti [6] from the results of his research states that mothers with chronically ill children limit activity such as should not play too long and too far and more rest at home.

All informants stated that the child was on chemotherapy treatment in hospital according to his protocol with vincristine and daunorubicin drugs. Children with leukemia should undergo chemotherapy treatment. This is supported Cahyono [7] in general the right treatment for cases of leukemia in children is chemotherapy and spinal marrow transplant. There are four stages of treatment for leukemia namely: stage 1 (induction therapy) by providing a combination of chemotherapy namely daunorubicin, vincristine, prednisone, and asparaginase. $\quad$ Stage 2 (consolidation/intensification therapy) to eliminate residual leukemia cells to prevent relapse and also the emergence of drug-resistant cells. This therapy is done after 6 months later. Stage 3 (CNS prophylaxis) uses different chemotherapy drugs, sometimes in combination with radiation therapy, to prevent leukemia from entering the brain and central nervous system. Stage 4 (long-term maintenance) to maintain the remission period. This stage usually takes 2-3 years.

c. Love the grief that mother experienced during caring for a child with leukemia From the results of this study, the mothers expressed sadness because they have to deal with chronically ill children and 
undergo a long treatment at the hospital. The responsibility of the mother in taking care of the child will also be greater. Because the child is hospitalized requires the mother to socialize to the patient and another family, the mother keeps each other in touch, give each other spirit and exchange information about the disease of his child. This is consistent with that written by Sunaryo [8] when a child suffers from a chronic illness such as leukemia, the duties, and responsibilities normally faced by a mother will increase and may make it difficult for other family members to deal with it normally. Due to the changing conditions, the mother as a human being must be able to adjust to the changing life in her family as the interaction between body, spirit, and environment.

\section{Problems Faced by the Mothers when} Caring Children with Leukemia

a. All the informants in this study stated that they had problems during the care of children with leukemia, the main problem they face is economic pressure, the cost of care and treatment for their children because all the costs for hospital treatment are not borne by BPJS if they want better medicine they use their own cost. Just as written in Permenkes number 59 of 2014 on tariff health care services in the implementation of health insurance programs, BPJS bear the cost based on disease level and inpatient class.
Informants also have cost issues for daily living in the hospital and transportation costs to the hospital because all informants are from outside the region. It is also written Aritonang [2] from the results of his research states, parents are experiencing severe economic pressures because of the costs incurred for care, treatment and to meet the nutritional needs of their children. Costs incurred by the family include transportation costs, the cost of meals during the hospital, and the cost of drugs that must be borne by the family. besides that also the daily needs of the family must be considered. The burden also increases in children who have gone to school. The family must meet the cost of education of their children, both sick and the healthy. And also from research Mostert [9] states that 40 parents $(78 \%)$ consider that the cost of care is one of the financial pressures faced by parents with childhood leukemia.

b. The way the mother overcomes the problems faced

Informants in this study complained about the cost issue of making mothers trying to seek help by utilizing assistance from the government BPJS (Board of Health Insurance Providers). In accordance with the written by Aritonang [2] the existence of financial pressure to make parents try to seek help from the family and use public health insurance from the 
government to help the burden of family care

Based on the results of this study all the informants revealed to overcome the problem of the cost of treatment of their children by utilizing the help of the government of BPJS (Health Insurance Provider Board) and the mother more frugal for other needs because they are less able to pay for expensive chemotherapy treatment. It is also written by Indriati [10] from the results of his research revealed Ms complained about the cost of treatment for her child with leukemia, but they are helped by the help from the government that is BPJS (Body Health Insurance Provider) to alleviate the cost of treatment of his child in the hospital. BPJS (Badan Penyelenggara Jaminan Kesehatan) is an institution established to organize social security program in Indonesia that serves to help the cost of medical treatment back treatment of acute or chronic men.

c. Help that mothers receive during caring for children with leukemia

From the results of this study, the mother is in need of assistance either social support assistance or material assistance from family, friends/neighbors, as well as from medical personnel. In line with the one written by Aritonan [2], the family is unable to meet all the needs of their children independently in terms of cost, support, energy and information fulfillment. Therefore, the family will look for parties that are considered capable of providing assistance. The family is the closest person to be asked for help. However, not all things can be expected to provide assistance because every family has its own stress and economic limitations as well. Assistance in taking care of children is one of the things expected of the family.

All informants stated that mothers get social support in the form of spirit, motivation, and information from family, friends/neighbors, mothers who have children with leukemia and medical personnel can reduce stress on the mother. In line with Christian research et al, social support has an important role in helping individuals survive psychologically. Social support is thought to reduce depression and enable individuals to survive in the face of emerging negative emotions.

The informants in the study also revealed that mothers received material assistance in the form of money for childcare and for daily expenses, meals, and gifts from family, friends/neighbors and foundations concerned with childhood illness. This is in accordance with Taylor [11] instrumental support ie real assistance involving the provision of material support, such as services, financial aid or goods. It is also written Shortman et al [12] state that family members help in 
child care, transportation, and financial support.

d. Impacts that occur in children

Informants in this study said children are more often in the hospital because they have to undergo a long treatment. As per Boyse [13], Children with chronic diseases will more often experience a hospitalization, treatment, and visits for medical examination with paramedics.

The results of this study showed that the mother cannot continue the school because they have to undergo chemotherapy in a hospital away from home and school. This is also written by Hernanti [6] from the results of his research stated that children with chronic disease of children's education are disturbed because they have to undergo transfusion every month in the hospital. The mother states the frequency of school children every month is disturbed around 2-5 days and if the child has a fever at home mother advised the child to rest at home.

e. Mother hopes for the future condition of the child

The results of this study all mothers expect no recurrence in their children and can be cured in order to move and school again. In line with Friedman's [14] family theory, especially parents, always expect the best for their children.

Informants in this study expect their children to recover and healthy again.
They worry about his son's future if his son continues to get sick. It is also written by Aritonang [2] the results of his research indicate a concern for the future of his son if asked about how their expectations for their children in the future, they hope to heal of their children. Concerns are due to a chronic illness suffered by their child is a disease that can not be cured.

\section{REFERENCES}

[1] Handayani, Wiwik \& Andi S.H. 2008. Buku Ajar Asuhan Keperawtan pada klien dengan Gangguan Sistem Hematlogi. Jakarta: Salemba Medika.

[2] Aritonang, M.V. 2008. Pengalaman keluarga merawat anak yang menderita penyakit kronis. Universitas Sumatra Utara, Medan.

[3] Maulyda, R, dkk. 2015. Tingkat Depresi Pada Ibu Yang Memiliki Anak Leukemia Limfoblastik Akut Di Ruang Rawat Estella Rsup Prof. Dr. R. D. Kandou Manado. Jurnal e-Clinic $(e \mathrm{Cl})$. 3(1)

[4] Kobblenzer, S.C. 2005. The Emotional Impact of Chronic and Dissabling Skin Disease: A Psychoanalitic Perspective. Dermatology Clinics. Volume 23.

[5] Putri, A.F. 2015. Dukungan orang tua yang memiliki anak dengan leukemia usia 6-12 tahun di RSU Kabupaten Tanggerang [skripsi]. Jakarta: Universitas Islam Negeri Syarif Hidayatullah.

[6] Hernanti, S.W.. 2015. Pengalaman Ibu Merawat Anak Usia Sekolah dengan Beta Thalassemia Mayor di RSUD Ulin Banjarmasin [skripsi]. Banjarmasin: Sekolah Tinggi Ilmu Kesehatan Sari 
Mulia Banjarmasin.Boyse, dkk. 2008. Children with Chronic Conditions. Diakses pada tanggal 04 Juni 2017 dari http://pediatrics.aapublications.org./cgi/ content/abstract/87/6/884.

[7] Cahyono, A. 2012. Gambaran tindakan orang tua yang mempunyai anak dengan penderita leukemia di ruang melati II RSUD dr. Moewardi [skripsi]. Surakarta: Universitas Muhammadiyah.

[8] Sunaryo. 2004. Psikologi untuk Keperawatan. Jakarta: EGC.

[9] Mostert et al. 2008. Parental Experiences of Childhood Leukemia Treatment in Indonesia. Journal of Pediatric Hematology/Oncology, 30(10).

[10] Indriati, G. 2011. Pengalaman Ibu Merawat Anak dengan Thalassemia di Jakarta. Tesis. Universitas Indonesia.

[11] Taylor, S. (2012). Health Psychology. New York:McGraw-Hill.

[12] Shortman et al. 2012. The Experience of Mothers Caring for a Child with a Brain Tumour. Child: care, health, and development. 39(5):743-749.

[13] Friedman, Marilyn M. 1995. Keperawatan Keluarga: Teori dan Praktik. Jakarta: EGC. 